\title{
Pengaruh Kesadaran Nilai, Integritas, Gratifikasi Personal, dan Penghindaran Risiko terhadap Sikap dan Perilaku pada Produk Lagu Bajakan
}

\author{
Sony Kusumasondjaja \& Syahrial Ashari, \\ Universitas Airlangga
}

\begin{abstract}
The increasing adoption of pirated music products in Indonesia intesifies the needs to understand factors influecing consumers to buy pirated music products. This study examines the impact of value consciousness, personal integrity, risk avoidance, and personal gratification on consumer attitude toward pirated music products and their intention to buy the products. Data was collected through mall-intercept survey distributed on several music concerts involving 150 music lovers. Findings suggest that consumers who are aware of product value tend to have favorable attitued and intention toward pirated music products, meanwhile consumers whose high level of personal integrity, risk avoidance, and personal gratification also have positive attitude and intention toward the pirated music products. Research contributions and implications are also discussed.
\end{abstract}

Kata Kunci: kesadaran nilai, risiko, sikap, niat konsumen, online marketing

\section{Latar Belakang Masalah}

Produk musik di Indonesia tidak saja berada pada ranah seni karena saat ini sudah berkembang menjadi industri yang cukup besar. Awal perkembangan industri musik di Indonesia ditandai dengan munculnya rekaman musik dalam pita kaset pada tahun 1967 setelah pada masa sebelumnya piringan hitam menjadi media rekaman produk musik. Kaset segera menggantikan peran piringan hitam karena alasan kepraktisan dan harga jual yang lebih murah. Dan alasan yang sama pula yang membuat konsumen Indonesia saat ini lebih memilih mendengarkan musik melalui Compact Disc daripada pita kaset. Penjualan fisik album CD di pasar Indonesia menunjukkan perkembangan yang cukup bagus. Menurut laporan Asosiasi Industri Rekaman Indonesia (ASIRI) Januari 2009, 85\% total penjualan produk musik Indonesia tahun 2008 dikuasai musik dalam negeri. Pada tahun 2006, total penjualan produk musik sebesar 26 juta kopi, tahun 2007 sebesar 19 juta kopi, sedangkan tahun 2008 total penjualan sebesar 15 juta kopi. Walaupun mengalami penurunan, penjualan musik Indonesia lebih besar dibandingkan penjualan musik luar negeri (Kompas, 2012).

Potensi industri musik juga berkembang seiring kemajuan teknologi saat munculnya peralihan dari teknologi analog ke digital pada awal tahun 2000. Perubahan teknologi tersebut membuat musisi lebih mudah merekam dan mengolah sendiri musiknya dengan lebih cepat. Kemajuan teknologi Internet juga memudahkan produser rekaman untuk mempromosikan dan mendistribusikan produk musik. Sayangnya, perkembangan teknologi digital dan Internet tidak hanya membantu perkembangan industri musik Indonesia karena pada saat yang bersamaan juga menciptakan musuh besar industri tersebut yang berwujud kemudahan pembajakan lagu. Asiri mencatat, sejak 2007 angka pembajakan produk rekaman musik mencapai lebih dari 90\%. Rasio peredaran album CD musik bajakan dan legal di tahun 2007 mencapai 96\% : 4\%, angka ini diprediksikan terus bertambah (Sindo, 2010). Hal ini berarti bahwa dari 10 kaset atau CD yang beredar hanya satu buah yang original dan legal. Asiri menghitung, setidaknya tiap tahun kerugian dari pembajakan ini mencapai Rp 1-2 triliun (Sindo, 2010). 
Salah satu hal yang mendorong semakin menjadi-jadinya transaksi pembajakan musik di era digital adalah kemudahan untuk memperoleh produk musik yang diinginkan. Konsumen tidak perlu pergi ke penjual CD pinggir jalan dan membayar 5000 rupiah. Cukup bermodalkan komputer dan koneksi Internet, konsumen dapat dengan mudah mengunduh dan mendengarkan lagu apapun yang diinginkan sebanyak apa pun melalui situs-situs file sharing dengan gratis. Bila dibandingkan dengan biaya memperoleh produk musik secara legal yang berkisar mulai Rp 25.000 hingga Rp 150.000 per keping CD, kemudahan dalam memperoleh dan menggunakan lagu bajakan menjadi alternatif menarik bagi konsumen Indonesia.

Selain itu, ukuran file lagu yang relatif lebih kecil daripada ukuran file film atau software membuat pembajakan lagu relatif lebih mudah dilakukan dan lebih sulit dihentikan daripada pembajakan film atau software. Apalagi, kemunculan lagu-lagu baru jauh lebih sering daripada kemunculan film atau software baru. Lagu-lagu tersebut biasa disimpan di perangkat-perangkat handheld terbaru seperti telepon genggam dan pemutar musik mobile untuk didengarkan sambil beraktivitas. Lebih-lebih lagi, saat ini sungguh mudah menemukan situs-situs Internet penyedia lagu-lagu populer yang dapat diunduh secara cuma-cuma. Tingginya kebutuhan dan adanya kemudahan inilah yang mendorong kegiatan pembajakan lagu melalui teknologi digital dan Internet.

Sebenarnya ada sebagian konsumen yang tidak meyakini atau tidak memahami bahwa tindakan tersebut termasuk perbuatan ilegal. Mereka yang memahami pun seringkali tidak peduli pada aturan hukum karena melihat tidak ketatnya sanksi hukum yang diberikan pada konsumen produk bajakan. Itulah sebabnya sebagian dari mereka tidak segan menggunakan musik gratis di tempat umum, memutarnya terang-terangan tanpa rasa takut, bahkan dengan eksplisit menyarankan atau menawarkan kepada teman-teman mereka yang lain untuk menggunakan lagu atau musik tersebut. Faktor yang lain yaitu tentang daya beli konsumen musik Indonesia yang cukup rendah, sehingga besar sekali keinginan konsumen untuk membayar lebih murah sebuah produk musik bajakan meskipun mendapatkan kualitas yang lebih rendah dibandingkan dengan produk yang asli. Dengan perbandingan harga yang sangat jauh, banyak konsumen musik Indonesia yang lebih memilih membeli produk bajakan daripada produk resmi.

Penelitian Gupta et al (2004) menemukan adanya beberapa faktor yang mempengaruhi konsumen untuk melakukan pembajakan produk secara ilegal. Faktor yang ditemukan mempengaruhi konsumen dalam melakukan pembajakan produk secara ilegal adalah kesadaran akan nilai produk (value consciousness), kecenderungan untuk menjaga sikap jujur dan sikap positif diri sendiri (integrity), kebutuhan untuk memperoleh pengakuan sosial (personal gratification), dan kecenderungan untuk menghindari kegiatan yang berisiko (risk aversion). Penelitian ini mengadaptasi penelitian Gupta et al. (2004) tersebut karena hasil penelitian empiris tentang sikap terhadap musik bajakan di Indonesia masih jarang ditemukan padahal hal ini marak terjadi. Penelitian ini berusaha untuk memberikan pemahaman tentang bagaimana kesadaran nilai produk, integritas, gratifikasi personal, dan penghindaran risiko berpengaruh pada sikap terhadap musik bajakan konsumen musik Indonesia.

Berdasarkan latar belakang yang telah diuraikan sebelumnya, pertanyaan yang dijawab oleh penelitian ini adalah (1) apakah kesadaran nilai, integritas, gratifikasi personal, dan penghindaran risiko berpengaruh secara simultan terhadap sikap pada produk lagu bajakan? dan (2) apakah sikap pada produk musik bajakan berpengaruh terhadap niat menggunakan produk lagu bajakan? 


\section{Landasan Teori}

\subsection{Manajemen Pemasaran dan Konsep Pemasaran}

Pemasaran menurut Kotler dan Keller (2012) dapat dibedakan atas definisi sosial serta manajerial. Definisi sosial dari pemasaran, yaitu suatu proses sosial dimana individu dan kelompok mendapatkan apa yang mereka butuhkan dan inginkan dengan menciptakan, menawarkan, dan menukar produk yang mempunyai nilai secara bebas dengan pihak lain. Sedangkan menurut definisi manajerial, pemasaran seringkali diartikan sebagai seni dalam menjual produk. Namun penjualan bukanlah hal yang paling penting dalam pemasaran itu sendiri. Peter Drucker dalam Kotler dan Keller (2012) menambahkan bahwa tujuan pemasaran adalah untuk mengetahui dan memahami konsumen dengan baik, sehingga produk yang dihasilkan dapat memenuhi keinginan dan kebutuhan konsumen, yang selanjutnya dapat meningkatkan penjualannya. Sedangkan The American Marketing Association memberikan definisi pemasaran sebagai proses dari perencanaan dan pelaksanaan konsep, penetapan harga, promosi, dan distribusi dari ide, barang, dan jasa untuk menciptakan pertukaran yang memuaskan tujuan individual maupun organisasional (Kotler dan Keller, 2012).

Perusahaan sekarang ini sudah banyak yang bergeser dari product-centered, dimana perusahaan hanya membuat dan menjual produk, ke customer-centered, dimana perusahaan berusaha untuk memahami dan merespon apa yang dibutuhkan dan diinginkan oleh konsumen. Tugas dari pemasaran sendiri bukanlah mencari konsumen yang tepat bagi produk, namun membuat produk yang tepat bagi konsumen. Kebutuhan dan keinginan konsumen menjadi fokus utama bagi perusahaan, dan filosofi consumer-oriented inilah yang kemudian dikenal dengan konsep pemasaran (Schiffman dan Kanuk, 2013).

Konsep pemasaran sendiri menurut Kotler dan Keller (2012) mengacu pada konsep yang menyatakan bahwa kunci untuk meraih tujuan organisasional adalah dengan menjadi lebih efektif daripada pesaing dalam menciptakan, mengantarkan, dan mengkomunikasikan nilai produk lebih tinggi kepada konsumen yang menjadi target pasarnya. Senada dengan yang dikemukakan oleh Kotler, Schiffman dan Kanuk (2013) menyatakan bahwa asumsi kunci yang mendasari konsep pemasaran adalah, untuk mencapai kesuksesan perusahaan harus menentukan kebutuhan dan keinginan konsumen dari target pasar yang spesifik dan memberikan kepuasan yang diharapkan dengan lebih baik dibandingkan dengan pesaing.

\subsection{Nilai Pelanggan dan Kesadaran Nilai}

Kotler dan Keller (2012) menyatakan bahwa customer value atau nilai pelanggan merupakan kombinasi kualitas pelayanan, harga dari suatu produk. Berdasarkan konsep ini, nilai pelanggan bersumber dari benefit ekonomi, benefit pelanggan dan benefit emosional. Buttle (2004) mengatakan bahwa pelanggan menggunakan istilah nilai untuk empat pengertian yang berbeda, yaitu:

1. Nilai adalah harga yang murah. Beberapa pelanggan mengatakan bahwa harga yang paling murah adalah nilai yang terbaik.

2. Nilai adalah mendapatkan apa yang diinginkan dari suatu produk atau jasa. Pelanggan ini mendefinisikan nilai dalam artian manfaat yang mereka terima dan bukannya harga yang mereka terima melainkan harga yang harus pelanggan bayar.

3. Nilai adalah kualitas yang didapatkan atas harga yang dibayar. Pelanggan menganggap nilai sebagai pertukaran antara harga yang mereka bayarkan dan kualitas yang mereka dapatkan. 
4. Nilai adalah semua yang didapatkan atas semua pengorbanan yang telah diberikan.

Perbedaan pandangan tentang nilai dapat ditangkap dalam sebuah definisi tentang nilai yaitu nilai adalah persepsi pelanggan tentang keseimbangan antara manfaat yang diterima dengan pengorbanan yang diberikan untuk mendapatkan manfaat tersebut. Kotler dan Keller (2012) mengatakan bahwa "Customer perceived value is difference between the perspective customer's evaluations of all beenfits and all the costs of an offering and the perceived alternatives". Bisa diartikan bahwa perceived value sebagai trade - off yang dihadapi konsumen antara kualitas dan harga yang dirasakan ketika mengevaluasi sebuah merek atau dengan kalimat lain bahwa customer value dihasilkan dari evaluasi konsumen atas keterkaitan antara harga yang harus mereka bayarkan dari kualitas yang akan mereka dapatkan dari produk yang akan mereka konsumsi.

Menurut Cateora dan Graham (2007) price-quality relationship dianggap ideal jika memenuhi harapan dasar dan tidak lebih, memungkinkannya untuk diberi harga secara kompetitif. Dalam beberapa situasi, konsumen mengembangkan harapan mengenai pricequality relationship (Mowen dan Minor, 2001:107). Secara umum, keterkaitan harga dan kualitas mendorong konsumen untuk mengharapkan produk berkualitas tinggi pada saat harga yang harus mereka bayarkan tinggi, begitu pula sebaliknya.

Bagi kebanyakan konsumen Indonesia yang menganggap harga sebagai komponen yang sangat penting dalam keputusan pembelian produk, faktor kesadaran pada nilai pelanggan (value consciousness) berperan penting dalam proses pengambilan keputusan tersebut. Lichtenstein et al. (1990) mendefinisikan value consciousness sebagai perhatian untuk membayar harga yang lebih rendah dengan kendala kualitas. Dalam konteks produk bajakan, penelitian sebelumnya menemukan bahwa harga merupakan elemen utama yang menentukan kecenderungan konsumen untuk membelinya (Maldonado dan Hume, 2005:110). Bloch et al. (1993) juga menambahkan bahwa ketika harga barang dari barang bajakan mempunyai keungggulan terhadap barang asli, maka konsumen akan lebih memilih barang bajakan. Menurut Shaari dan Halim (2006) produk bajakan biasanya akan sedikit mengabaikan kualitas barang. Mereka tidak mengharapkan kualitas yang tinggi dari barang bajakan, melainkan lebih pada manfaat fungsionalnya.

\subsection{Integritas Personal}

Teori psikoanalitik yang dikemukakan Sigmund Freud menunjukkan bahwa perilaku manusia dikuasai oleh kepribadiannya. Mowen dan Minor (2001) menjelaskan bahwa kepribadian atau personality sendiri berasal dari perjuangan dinamis antara dorongan fisiologis dalam diri dan tekanan sosial untuk menaati hukum, aturan, dan kode moral. Tekanan sosial untuk menaati hukum, aturan, dan kode moral timbul dari sistem superego seseorang. Superego adalah sesuatu yang ideal yang ada dalam diri manusia serta dapat menjadi motivasi untuk bertindak secara bermoral dan menaati hukum. Pernyataan diatas didukung oleh moral competence theory dari Kohlberg (1976), yang menyatakan bahwa perilaku konsumen dapat dipengaruhi oleh perasaan terhadap hukum (personal sense of justice) dari konsumen itu sendiri.

Integrity berkaitan dengan standar etika dan kepatuhan konsumen terhadap hukum (Wang et al., 2005:342). Steenhaut dan Van Kenhove (2006) dalam Phau dan Teah (2009) menyatakan bahwa pengaruh nilai dasar seperti integrity dapat mempengaruhi keputusan untuk tidak bertindak tidak etis. Dijelaskan oleh Ang et al. (2001) dalam penelitiannya di konteks konsumsi produk bajakan, konsumen yang lawful-minded dan memiliki integritas tinggi cenderung untuk tidak berhubungan dengan barang bajakan. Sebaliknya konsumen yang 
mempunyai integritas yang rendah cenderung untuk merasa tidak bertanggung jawab dengan tindakannya dalam mengkonsumsi produk bajakan.

\subsection{Gratifikasi Personal}

Personal gratification berkaitan dengan keinginan konsumen untuk memperoleh pemenuhan atas apa yang diinginkan, mendapatkan pengakuan sosial, serta menikmati kenyamanan dalam hidup (Phau dan Teah, 2009). Dijelaskan oleh Phau dan Teah (2009) bahwa konsumen yang memiliki perasaan mengenai personal gratification yang tinggi mempunyai kecenderungan yang rendah untuk dapat menerima produk dengan kualitas sedikit rendah. Dalam konteks penelitian produk bajakan, konsumen yang memiliki personal gratification yang tinggi cenderung untuk mengkonsumsi produk berkualitas tinggi karena memberikan jaminan kenyamanan lebih besar bagi diri mereka dalam proses konsumsinya (Phau dan Teah, 2009). Sebaliknya, konsumen yang membeli barang bajakan bersedia untuk mengorbankan kualitas dan jaminan kenyamanan yang diasosiasikan dengan barang asli. Konsumen dengan personal gratification rendah tidak menilai kenikmatan dengan memiliki barang dengan kualitas yang lebih baik, serta tidak memiliki perasaan memperoleh prestasi atau penghargaan dengan memiliki barang asli (Ang et al., 2001:224).

\subsection{Risk Avoidance}

Fraedrich dan Ferrell (1992) mengukur dampak risiko yang dirasakan dan filsafat moral pada pembuatan keputusan secara etis. Hal ini diringkas enam aspek risiko, yaitu keuangan, kinerja, fisik, psikologis, sosial, dan risiko secara keseluruhan, dari literatur masa lalu. Menurut Tan (2002), keuangan, kinerja, sosial, dan penuntutan adalah aspek yang paling penting dari risiko yang berlaku di konteks pembajakan perangkat lunak. Begitu pun pada pembajakan musik, berfokus pada efek risiko penuntutan sikap pembajakan untuk alasan berikut. Pertama, karenabiaya pembelian $C D$ musik bajakan tidak sangat mahal, risiko keuangan sangat rendah. Kedua, seperti yang disebutkan, dengan munculnya era digital, performance CD bajakan biasanya dapat memiliki kualitas sebagus asli satu. Oleh karena itu, risiko performance tidak sangat kuat. Akhirnya, konsep risiko sosial sangat mirip dengan konsep konsensus sosial di literatur intensitas moral. Untuk mempermudah, konsep risiko pengaruh sosial akan dimasukkan di bagian berikutnya tentang intensitas moral. Hampir sama dengan pendapat Tan (2002), Chiou, Huang dan Lee (2005) mengusulkan bahwa risiko sangat penting dalam mempengaruhi sikap pembajakan konsumen. Perilaku membeli CD musik bajakan adalah melanggar hak cipta. Konsumen akan menanggung risiko tindakan hukum oleh pemegang hak cipta.

\subsection{Sikap Konsumen}

Peter dan Olson (1999:120) mendefinisikan sikap secara umum sebagai evaluasi menyeluruh dari seseorang terhadap sebuah konsep. Secara spesifik, Schiffman dan Kanuk (2013:253) menyatakan, "In a consumer behavior context, an attitude is a learned predisposition behave in a consistenly favorable or unfavorable way with respect to a given object." Artinya adalah dalam konteks perilaku konsumen, sikap merupakan pembelajaran dari kecenderungan seseorang untuk berperilaku dengan cara menyukai atau tidak menyukai secara konsisten terhadap suatu objek.

Sikap terdiri dari tiga komponen penting, yaitu komponen kognitif (cognitive component), komponen afektif (affective component), dan komponen konatif (conative component), yang disebut tricomponent attitude model (Schiffman dan Kanuk, 2013:256). Komponen pertama adalah kognisi, yaitu pengetahuan dan persepsi yang didapat dari kombinasi antara pengalaman dari sikap terdahulu dan informasi yang diperoleh dari berbagai sumber. 
Pengetahuan dan pengalaman tersebut diperoleh dari bentuk kepercayaan (beliefs), dimana konsumen percaya bahwa sikap memiliki berbagai atribut dan perilaku tertentu yang akan mengarah pada hasil tertentu pula. Kedua, afeksi adalah emosi atau perasaan dari konsumen tentang produk atau merek. Emosi dan perasaan tersebut seringkali diperlakukan oleh para peneliti sebagai evaluasi dasar, maksudnya adalah emosi dan perasaan tersebut merupakan penilaian umum seseorang terhadap sesuatu. Dan, komponen ketiga adalah konatif yang berkaitan dengan kecenderungan seseorang untuk bertindak secara khusus terhadap sesuatu.

Attitude Towars Piracy merupakan bentuk dari attitude-toward-object model yang merupakan salah satu tipe dari multiattribute attitude models. Multiattribute attitude models menggambarkan sikap dari konsumen terhadap sesuatu yang merupakan fungsi dari persepsi konsumen dan penilaian atribut-atribut atau kepercayaan pada objek khusus (Schiffman dan Kanuk, 2013:259). Schiffman dan Kanuk (2013:259) mengatkan bahwa attitude-towardobject model merupakan model yang sesuai untuk mengukur sikap terhadap suatu kategori produk (atau jasa) atau merek tertentu. Berdasarkan model tersebut, sikap konsumen terhadap suatu kategori produk (atau jasa) atau merek tertentu. Berdasarkan model tersebut, sikap konsumen terhadap sebuah produk atau merek tertentu merupakan fungsi dari kehadiran (atau ketidakhadiran) serta evaluasi dari kepercayaan dan atau atibut-atribut yang ada dalam produk tertentu. Dengan kata lain, konsumen secara umum bersikap suka terhadap suatu produk yang mereka percaya mempunyai atribut-atribut yang dinilai positif, sebaliknya konsumen akan bersikap tidak suka terhadap suatu produk yang mereka anggap idak mempunyai atribut-atribut yang dapat memberi kepuasan.

Menurut Ang et al. (2001) terdapat beberapa faktor yang mempengaruhi attitude toward piracy dari konsumen yaitu kesadaran nilai, integritas, gratifikasi personal, dan penghindaran risiko. Mowen dan Minor (2010) mengemukakan dua model dari multiattribute models untuk mengidentifikasi bagaimana konsumen mengkombinasikan kepercayaan mereka tentang atribut produk untuk membentuk sikap terhadap berbagai alternative merek, korporasi, atau objek lainnya. Dua model tersebut adalah model sikap terhadap objek, atau model Fishbein dan model keinginan berperilaku.

\subsection{Niat untuk Menggunakan Produk}

Seluruh tindakan konsumen dalam memutuskan untuk menggunakan dan tidak menggunakan suatu produk berawal dari niat. Niat berkaitan dengan keinginan terhadap suatu hal yang biasanya diikuti oleh tingkah laku yang mendukung keinginan tersebut. Niat (intention) merupakan keinginan berperilaku yang didefinisikan sebagai keinginan konsumen untuk berperilaku menurut cara tertentu dalam rangka memiliki, membuang, dan menggunakan produk atau jasa. Jadi, konsumen dapat membentuk keinginan untuk mencari informasi, memberitahukan orang lain tentang pengalamannya dengan sebuah produk, membeli produk atau jasa tertentu, atau membuang produk dengan cara tertentu (Mowen dan Minor, 2002:322).

Dalam penelitiannya, Ajzen dan Fishben (1980) mengasumsikan behavioral intention sebagai "the motivational factors that influence a behavior, they are indications of how hard people are willing to try, of how much of an effort they are planning to exert, in order to perform the behavior." Berdasarkan Theory of Reasoned Action, faktor yang mempengaruhi niat adalah sikap pada tindakan, dan norma subyektif menyangkut persepsi seseorang, apakah orang lain yang dianggap penting akan mempengaruhi perilakunya (Schiffman dan Kanuk, 2013). Berdasarkan penelitian dari Ajzen (1998), Schiffman dan Kanuk (2013) mendefinisikan niat berperilaku (intention) sebagai kecenderungan seseorang untuk memilih melakukan atau 
tidak melakukan suatu pekerjaan. Niat untuk menggunakan produk diawali oleh adanya kesadaran akan kebutuhan dan adanya sikap positif terhadap suatu produk.

\section{Pengembangan Hipotesis}

Penelitian sebelumnya mengenai pengaruh kesadaran nilai, integritas, gratifikasi personal, dan penghindaran risiko terhadap niat untuk menggunakan melalui sikap terhadap produk bajakan dilakukan oleh Phau dan Ng (2009), dalam penelitian yang berjudul "Predictors of Usage Intention of Pirated Software". Penelitian ini mempunyai beberapa tujuan, yaitu untuk mengetahui perbedaan sikap antara konsumen yang menggunakan dan tidak menggunakan software bajakan. Tujuan lain dari penelitian ini adalah untuk mengetahui bagaimana pengaruh antara kesadaran nilai, integritas, gratifikasi personal, dan penghindaran risiko terhadap sikap pada software bajakan. Selain itu, juga meneliti apakah sikap pada software bajakan berpengaruh terhadap niat untuk menggunakan software bajakan. Hasil dari penelitian ini menyatakan bahwa sikap pada software bajakan dipengaruhi positif oleh kesadaran nilai dan dipengaruhi secara negatif oleh penghindaran risiko. Sedangkan integritas dan gratifikasi personal bukan merupakan variabel yang berpengaruh signifikan terhadap sikap pada software bajakan. Hasil lainnya adalah bahwa sikap pada software bajakan mempunyai pengaruh yang signifikan terhadap niat untuk menggunakan software bajakan.

Persamaan penelitian ini dengan penelitian yang dilakukan oleh Ian Phau dan James $\mathrm{Ng}$ (2009), adalah variabel yang dipakai seluruhnya sama. Penelitian ini juga menggunakan kesadaran nilai, integritas, gratifikasi personal dan penghindaran risiko sebagai variabel bebas, sikap terhadap produk bajakan sebagai variabel intervening, dan niat untuk menggunakan produk bajakan sebagai variabel terikat. Sedangkan perbedaan penelitian ini dengan penelitian sebelumnya adalah penelitian ini menggunakan musik sebagai obyek penelitian. Phau dan Ng (2009) menggunakan software sebagai obyeknya. Selain itu penelitian ini tidak menambahkan dua faktor yang ditambahkan Phau dan Ng (2009) yaitu normative dan informative susceptibility sebagai variabel bebas, karena pada penelitian tersebut tidak memiliki pengaruh pada sikap terhadap produk bajakan.

Kesadaran nilai adalah persepsi konsumen terhadap harga dan kualitas produk, apakah harga yang konsumen bayarkan sesuai dengan kualitas produk yang didapatkan (Zeithaml 1988, p. 14). Orang yang mempunyai kesadaran nilai tinggi diperkirakan mempunyai sikap terhadap produk bajakan yang positif. Hal ini disebabkan oleh persepsi konsumen yang menganggap produk bajakan mempunyai manfaat fungsional yang sama dengan produk versi asli, dengan harga yang lebih murah (Wang et al., 2005:342). Berdasarkan penjelasan ini, diajukan hipotesis sebagai berikut:

\section{H1: Kesadaran nilai berpengaruh positif terhadap sikap pada produk lagu bajakan.}

Integritas berkaitan dengan etika dan kepatuhan konsumen terhadap hukum. Cordell et al. (1996) dalam Ang et al. (2001) berpendapat bahwa konsumen yang lebih lawful-minded mempunyai kecenderungan yang rendah untuk membeli barang bajakan. Sedangkan konsumen yang mempunyai standar etika yang rendah lebih tidak mempunyai tanggung jawab apabila membeli barang bajakan. Sehingga mereka tidak menganggap bahwa tindakan mereka tidak etis. Jadi, dengan membandingkan dengan konsumen yang mempunyai integritas rendah, maka konsumen yang memiliki integritas tinggi diperkirakan mempunyai sikap negatif terhadap sikap pada produk bajakan (Ang et al., 2001:224). Berdasarkan penjelasan ini, diajukan hipotesis sebagai berikut: 


\section{H2: Integritas diri berpengaruh negatif terhadap sikap pada produk lagu bajakan.}

Gratifikasi personal berhubungan dengan kebutuhan konsumen untuk mendapatkan pemenuhan atas apa yang diinginkan, mendapatkan pengakuan sosial, serta menikmati kenyamanan dalam hidup Ang et al., (2001). Berdasarkan pengamatan yang dilakukan oleh Bloch et al., (1993), konsumen yang membeli barang bajakan memiliki kepercayaan diri yang rendah, kurang sukses, dan merasa statusnya rendah sehingga kebutuhan untuk memberikan gratifikasi untuk dirinya sendiri pun rendah. Maka, konsumen yang lebih ingin memperoleh gratifikasi personal yang tinggi diperkirakan mempunyai sikap negatif terhadap produk bajakan.

\section{H3: Gratifikasi personal berpengaruh negatif terhadap sikap pada produk lagu bajakan.}

Penghindaran risiko dalam konteks ini mengacu pada tingkat toleransi risiko individu untuk terlibat dalam aktivitas ilegal yang berhubungan dengan produk bajakan. Karakteristik pribadi konsumen tentang risk aversion merupakan komponen yang cukup penting dalam pengambilan keputusan konsumen. Hal ini dapat disimpulkan dari apa yang dikatakan Hofstede dan Bond, (1984) tentang definisi risk aversion yakni sejauh mana seseorang merasa dirinya terancam oleh situasi yang tidak pasti, dan kemudian menciptakan keyakinannya sendiri yang bertujuan untuk mencoba menghindari kondisi ketidakpastian tersebut. Oleh karena pengambilan keputusan konsumen sudah pasti tidak dapat dihindarkan dari adanya faktor risiko, (Cunningham et al. 2005) maka konsumen secara otomatis akan menciptakan suatu perilaku tertentu sebagai bentuk pertahanan diri untuk menghindari segala bentuk risiko yang dapat muncul dari keputusannya tersebut. Sementara kepedulian terhadap kesadaran nilai dapat mempengaruhi individu untuk menggunakan produk bajakan, takut terhadap hukuman pidana juga harus dapat mencegah perilaku tersebut (Albers-Miller, 1999). Literatur menyelidiki keterlibatan konsumen dalam perilaku terlarang telah menunjukkan bahwa ada hubungan terbalik antara keseriusan dari hukuman dan tindak kriminal. Penelitian juga telah membuktikan bahwa ada juga hubungan terbalik antara kemungkinan tertangkap yang dirasakan dan perilaku kriminal (Hollinger and Clark, 1983). Sebaliknya, dapat juga dikatakan bahwa ada kecenderungan yang lebih tinggi untuk terlibat dalam kegiatan "gelap" jika ada anggapan resiko tertangkap yang lebih rendah. Oleh karena itu, keuntungan yang didapatkan dalam hal sikap terhadap musik bajakan mungkin dibatasi oleh rasa takut tertangkap dan dihukum oleh hukum. Hal ini dapat dikatakan bahwa hukum hak cipta dan beratnya hukuman menempatkan kontrol perilaku individu atas niat untuk menggunakan produk bajakan. Kemudian disimpulkan dalam Phau dan Ng (2009) bahwa seseorang yang lebih menghindari risiko lebih cenderung memiliki sikap negatif terhadap produk lagu bajakan.

\section{H4: Penghindaran risiko berpengaruh negatif terhadap sikap pada produk lagu bajakan.}

Teori perilaku terencana (TPB) yang mencakup sikap, norma subyektif, dan kendali perilaku jelas memiliki pengaruh terhadap niat seseorang untuk menggunakan musik secara ilegal. Seperti yang telah dikemukakan oleh Beck dan Ajzen (1991), bahwa TPB secara akurat mampu memprediksi perilaku tidak jujur seseorang. Sehingga, landasan seseorang untuk menggunakan musik secara ilegal juga dapat diprediksi menggunakan TPB seperti halnya yang dilakukan peneliti sebelumnya untuk meneliti hal-hal yang mendahului pembajakan musik (Wang dkk., 2009). Unsur pertama dalam TPB ialah sikap. Sikap dijelaskan melalui tindakan seseorang pada suatu perilaku tertentu merupakan faktor penting yang mendahului niat (Ajzen, 1985). Pembentukan sikap terjadi akibat pengaruh yang kuat oleh pengalaman pribadi, pengaruh keluarga dan teman, pemasaran langsung, dan media massa (Schiffman dan 
Kanuk, 2013). Kemudian disimpulkan dalam Wang dkk. (2009) bahwa semakin positif sikap seseorang terhadap sesuatu, maka makin besar juga niat seseorang dalam melakukan hal tersebut.

\section{H5: Sikap pada produk lagu bajakan berpengaruh positif terhadap niat menggunakan musik bajakan.}

Berdasarkan uraian pengembangan hipotesis di atas, model analisis yang digunakan pada penelitian ini adalah sebagai berikut:

\section{Gambar 1. Model Analisis}

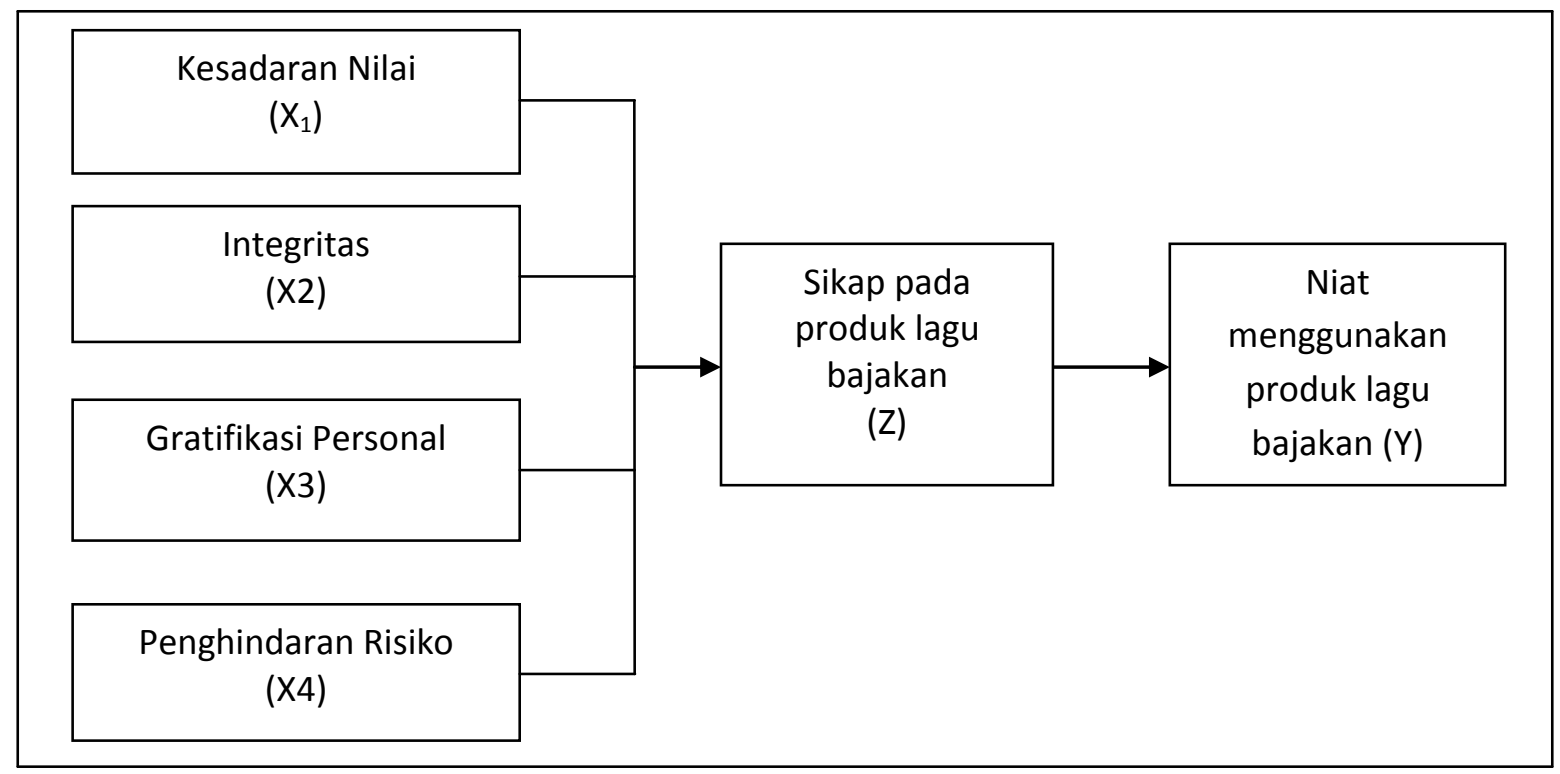

\section{Metode Penelitian}

Penelitian ini merupakan penelitian kuantitatif eksplanatori yang bertujuan untuk menjelaskan pengaruh kesadaran nilai, integritas diri, penghindaran risiko, dan gratifikasi terhadap sikap konsumen terhadap produk musik bajakan serta niat konsumen untuk mengkonsumsinya. Populasi adalah wilayah generalisasi yang terdiri atas obyek atau subyek yang mempunyai kuantitas atau karakteristik tertentu yang ditetapkan oleh peneliti untuk dipelajari (Malhotra, 2006). Populasi dari penelitian ini ialah Generasi Y yang berdomisili di Surabaya, dikarenakan Generasi Y lebih heterogen dalam istilah rasial dan sosioekonomis daripada Generasi X (Mowen and Minor, 2001). Generasi Y adalah 72 juta anak-anak dari Generasi X, di mana yang pertama akan mencapai dewasa pada tahun 2000. Generasi Y adalah mereka yang lahir antara tahun 1978 dan 2000 (Yarrow and O'Donnell, 2009), yang berarti saat ini mereka berusia 13 tahun sampai dengan 35 tahun, yang mewakili 28 persen dari populasi sekarang dan menyaingi 30 persen Generasi X yang dilahirkan antara tahun 1965 dan 1980 (Mowen and Minor, 2001). Sampel penelitian ini adalah konsumen musik Indonesia yang pernah membeli atau mengunduh musik bajakan dalam kurun waktu satu tahun terakhir.

Instrumen yang digunakan untuk pengumpulan data adalah kuesioner yang disebarkan pada beberapa acara konser musik di Surabaya untuk memperoleh responden yang memang secara intensif mengkonsumsi musik. Terdapat sejumlah 150 responden yang berpartisipasi pada 
penelitian ini. Karakteristik responden yang terlibat dalam penelitian ini adalah $52 \%$ pria, $75 \%$ berusia di bawah 30 tahun, 35\% berstatus mahasiswa, 33\% memiliki pendapatan per bulan di atas Rp 3.500.000,-.

Indikator yang digunakan untuk mengukur variabel kesadaran nilai diadaptasi dari Lichtenstein et al. (1990), sedangkan indikator variabel integritas dikembangkan dari penelitian Vinson et al (1997), ). indikator gratifikasi personal dikembangkan dari Ang et al. (2001:227), dan indikator variabel penghindaran risiko dalam penelitian ini dikembangkan dari penelitian Donthu and Gilliland (1996). Untuk mengukur variabel sikap pada produk musik bajakan digunakan indikator yang diadaptasi dari Kwong et al (2003), sementara pengukuran yang digunakan untuk menilai niat untuk menggunakan produk musik bajakan diadaptasi dari Wang et al. (2005:350). Indikator-indikator yang digunakan untuk mengukur variabel penelitian tersaji pada Tabel 1 .

Item di kuesioner disajikan dengan menanyakan tingkat kesetujuan responden atas pernyataan-pernyataan yang tersaji. Pengukuran dilakukan dengan menggunakan skala Likert 1-5, di mana 1 menunjukkan sangat tidak setuju dan 5 menunjukkan sangat setuju. Pengujian reliabilitas dan validitas menunjukkan bahwa semua item di kuesioner dinilai reliabel dan valid. Untuk menganalisis data, menguji hipotesis, dan menguji model penelitian, penelitian ini menggunakan program SPSS versi 18.

\section{Tabel 1}

\section{Indikator Variabel Penelitian}

\begin{tabular}{|c|c|c|}
\hline Variabel & Indikator & Referensi \\
\hline Kesadaran Nilai & $\begin{array}{l}\text { a. Saya sangat peduli tentang harga murah, } \\
\text { tapi saya juga peduli tentang kualitas } \\
\text { produk. } \\
\text { b. Ketika berbelanja, saya membandingkan } \\
\text { harga produk dari merek yang berbeda } \\
\text { untuk memastikan saya mendapatkan } \\
\text { harga terbaik. } \\
\text { c. Ketika membeli sebuah produk, saya } \\
\text { selalu mencoba untuk mendapatkan } \\
\text { kualitas yang maksimal untuk uang yang } \\
\text { saya habiskan. } \\
\text { d. Ketika saya membeli produk, saya ingin } \\
\text { memastikan bahwa saya menjadikan uang } \\
\text { saya bernilai. } \\
\text { e. Saya biasanya berbelanja untuk harga } \\
\text { yang lebih murah, tapi masih harus } \\
\text { memenuhi persyaratan kualitas tertentu } \\
\text { sebelum saya akan membelinya. } \\
\text { f. Saat saya berbelanja, saya biasa } \\
\text { membandingkan informasi harga setiap } \\
\text { barang untuk merek yang saya beli } \\
\text { biasanya. } \\
\text { g. Saya selalu memeriksa harga produk di } \\
\text { toko kelontong, untuk memastikan bahwa } \\
\text { saya mendapatkan nilai terbaik untuk uang } \\
\text { yang saya habiskan. }\end{array}$ & Lichtenstein et al (1990) \\
\hline
\end{tabular}




\begin{tabular}{|c|c|c|}
\hline Integritas Personal & $\begin{array}{l}\text { a. Saya tidak mau menggunakan produk } \\
\text { bajakan. } \\
\text { b. Saya menghargai hasil kerja orang lain } \\
\text { dengan cara tidak menggunakan produk } \\
\text { bajakan } \\
\text { c. Saya lebih suka menggunakan produk lagu } \\
\text { asli meski harganya lebih mahal. }\end{array}$ & Vinson et al. (2000) \\
\hline Gratifikasi Personal & $\begin{array}{l}\text { a. Penting bagi saya untuk mendapatkan } \\
\text { hidup yang nyaman. } \\
\text { b. Penting bagi saya untuk mendapatkan } \\
\text { hidup yang menyenangkan. } \\
\text { c. Penting bagi saya untuk mendapatkan apa } \\
\text { yang saya inginkan. } \\
\text { d. Saya adalah orang yang menghargai } \\
\text { kesenangan diri. } \\
\text { e. Saya adalah orang yang menghargai } \\
\text { pengakuan sosial. }\end{array}$ & Ang et al. (2001) \\
\hline Penghindaran risiko & $\begin{array}{l}\text { a. Saya lebih suka menjadi aman daripada } \\
\text { menyesal karena menggunakan produk } \\
\text { bajakan. } \\
\text { b. Saya ingin memastikan risiko yang bisa } \\
\text { saya hadapi sebelum menggunakan produk } \\
\text { bajakan } \\
\text { c. Saya menghindari hal-hal yang berisiko } \\
\text { karena menggunakan produk bajakan. }\end{array}$ & $\begin{array}{l}\text { Donthu and Gilliland } \\
\text { (1996) }\end{array}$ \\
\hline Sikap & $\begin{array}{l}\text { a. Saya pikir itu adalah positif bagi saya untuk } \\
\text { membeli produk bajakan jika kebanyakan } \\
\text { orang melakukannya. } \\
\text { b. Saya pikir itu adalah positif bagi saya untuk } \\
\text { membeli produk bajakan jika saya tidak } \\
\text { akan membeli satupun yang asli dalam } \\
\text { kondisi apapun. } \\
\text { c. Saya pikir itu adalah positif bagi saya untuk } \\
\text { membeli produk bajakan }\end{array}$ & Kwong et al. (2003) \\
\hline $\begin{array}{l}\text { Niat Menggunakan } \\
\text { Produk Bajakan }\end{array}$ & $\begin{array}{l}\text { a. Saya akan merekomendasikan untuk } \\
\text { menggunakan produk lagu bajakan kepada } \\
\text { orang lain. } \\
\text { b. Bila ada permintaan, saya akan } \\
\text { mempertimbangkan untuk memberikan } \\
\text { produk lagu bajakan untuk digunakan oleh } \\
\text { orang lain. } \\
\text { c. Saya akan mempertimbangkan untuk } \\
\text { menggunakan produk lagu bajakan sebagai } \\
\text { alternatif pilihan. } \\
\text { d. Saya akan menggunakan produk lagu bajakan. }\end{array}$ & Wang et al. (2003) \\
\hline
\end{tabular}

\section{Hasil dan Pembahasan}

Analisis regresi linier berganda digunakan untuk mengetahui besarnya pengaruh variabel independen terhadap variabel dependen, dalam hal ini adalah pengaruh variabel Kesadaran Nilai $\left(X_{1}\right)$, Integritas $\left(X_{2}\right)$, Gratifikasi Personal $\left(X_{3}\right)$ dan Penghindaran Risiko $\left(X_{4}\right)$ dengan Sikap Pada Produk Lagu Bajakan (Z). Berikut akan dipaparkan hasil pengujian regresi linier berganda : 
Tabel 1.

\section{Besarnya Pengaruh Variabel Kesadaran Nilai $\left(\mathrm{X}_{1}\right)$, Integritas $\left(\mathrm{X}_{2}\right)$, Gratifikasi Personal $\left(\mathbf{X}_{3}\right)$ dan Penghindaran Risiko $\left(\mathbf{X}_{4}\right)$ Terhadap Sikap Pada Produk Lagu Bajakan (Z)}

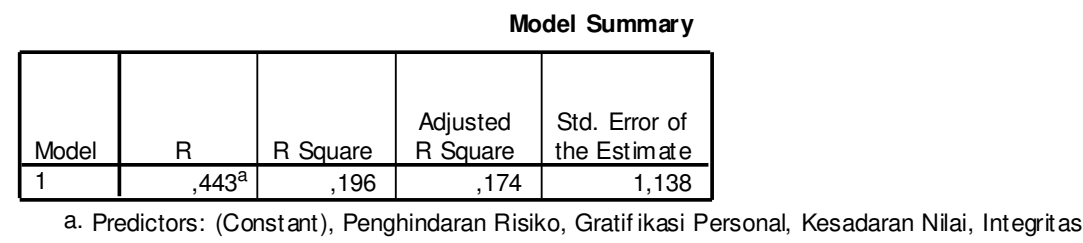

Berdasarkan Tabel 1 di atas, dapat diperoleh beberapa bahwa kolom $\mathrm{R}$ menunjukkan bahwa korelasi/hubungan antara variabel Kesadaran Nilai $\left(\mathrm{X}_{1}\right)$, Integritas $\left(\mathrm{X}_{2}\right)$, Gratifikasi Personal $\left(\mathrm{X}_{3}\right)$ dan Penghindaran Risiko $\left(\mathrm{X}_{4}\right)$ dengan Sikap Pada Produk Lagu Bajakan $(\mathrm{Z})$ sebesar 0,443 atau sebesar $44,3 \%$ atau kurang kuat. Kolom $R$ square atau koefisien determinasi adalah 0,196. Hal ini berarti bahwa $19,6 \%$ variasi variabel Kesadaran Nilai $\left(\mathrm{X}_{1}\right)$, Integritas $\left(\mathrm{X}_{2}\right)$, Gratifikasi Personal $\left(\mathrm{X}_{3}\right)$ dan Penghindaran Risiko $\left(\mathrm{X}_{4}\right)$ Terhadap Sikap Pada Produk Lagu Bajakan (Z) sedangkan sisanya dijelaskan oleh sebab-sebab lain. Standard error of estimate (SEE) adalah 1,138. makin besar SEE akan membuat model regresi kurang tepat dalam memprediksi variabel dependen.

Tabel 2.

\section{Hasil Pengujian Regresi Linier Berganda}

\begin{tabular}{|c|c|c|c|c|}
\hline & & \multicolumn{3}{|c|}{ Coefficients $s^{a}$} \\
\hline & & \multicolumn{2}{|c|}{$\begin{array}{l}\text { Unstandardized } \\
\text { Coeff icients }\end{array}$} & $\begin{array}{l}\text { Standardized } \\
\text { Coeff icients }\end{array}$ \\
\hline \multicolumn{2}{|c|}{ Model } & $\mathrm{B}$ & Std. Error & Beta \\
\hline & (Constant) & 20,442 & 1,513 & \\
\hline & Kesadaran Nilai & ,091 &, 031 & 219 \\
\hline & Integritas &,- 164 & ,058 &,- 216 \\
\hline & Gratifikasi Personal &,- 111 &, 043 &,- 193 \\
\hline & Penghindaran Risiko &,- 223 & ,053 &,- 323 \\
\hline
\end{tabular}

Berdasarkan Tabel 2 di atas maka persamaan regresi linier berganda yang diperoleh dalam penelitian ini serta bermanfaat untuk mengetahui arah perubahan variabel kesadaran nilai $\left(\mathrm{X}_{1}\right)$, integritas $\left(\mathrm{X}_{2}\right)$, gratifikasi personal $\left(\mathrm{X}_{3}\right)$ dan penghindaran risiko $\left(\mathrm{X}_{4}\right)$ terhadap sikap pada produk lagu bajakan $(\mathrm{Z})$ adalah sebagai berikut :

$$
Y=20,442+0,091 X_{1}-0,164 X_{2}-0,111 X_{3}-0,223 X_{4}+e
$$

Analisis regresi linier berganda digunakan untuk mengetahui besarnya pengaruh variabel independen terhadap variabel dependen, dalam hal ini adalah pengaruh variabel sikap pada produk (Z) terhadap Niat untuk Menggunakan Produk Lagu Bajakan (Y). Berikut akan dipaparkan hasil pengujian regresi linier berganda : 
Tabel 3

\section{Besarnya Pengaruh Variabel Sikap Pada Produk (Z) Terhadap Niat Untuk Menggunakan Produk Lagu Bajakan (Y)}

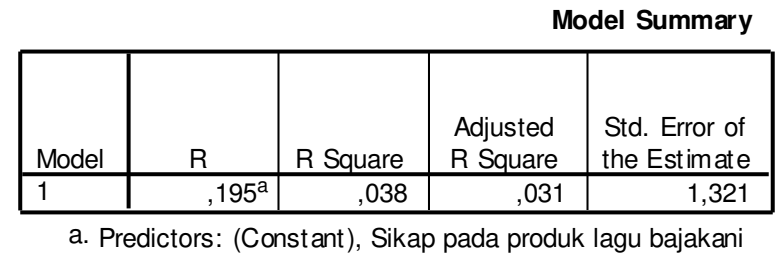

Berdasarkan Tabel 3 di atas, dapat dilihat bahwa kolom $\mathrm{R}$ menunjukkan bahwa korelasi/hubungan antara variabel sikap pada produk $(\mathrm{Z})$, dengan niat untuk menggunakan produk lagu bajakan (Y) sebesar 0,195 atau sebesar 19,5\% atau kurang kuat. Kolom $R$ square atau koefisien determinasi adalah 0,038. Hal ini berarti bahwa 38\% variasi variabel sikap pada produk $(Z)$, sedangkan sisanya dijelaskan oleh sebab-sebab lain. Standard error of estimate (SEE) adalah 1,321. makin besar SEE akan membuat model regresi kurang tepat dalam memprediksi variabel dependen.

Tabel 4.

\section{Hasil Pengujian Regresi Linier Berganda}

\begin{tabular}{|c|c|c|c|c|}
\hline & & \multicolumn{3}{|c|}{ Coefficients } \\
\hline \multirow[b]{2}{*}{ Model } & & \multicolumn{2}{|c|}{$\begin{array}{l}\text { Unstandardized } \\
\text { Coeff icients }\end{array}$} & \multirow{2}{*}{$\begin{array}{c}\text { Standardized } \\
\text { Coeff icients } \\
\text { Beta }\end{array}$} \\
\hline & & B & Std. Error & \\
\hline & (Constant) & 14,210 & 1,402 & \\
\hline & $\begin{array}{l}\text { Sikap pada produk } \\
\text { lagu bajakani }\end{array}$ & &, 086 & , 195 \\
\hline
\end{tabular}

Berdasarkan Tabel 4 di atas maka persamaan regresi linier berganda yang diperoleh dalam penelitian ini serta bermanfaat untuk mengetahui arah perubahan variabel sikap pada produk (Z), terhadap niat untuk menggunakan produk lagu bajakan (Y) adalah sebagai berikut :

$$
Y=14,210+0,209 X_{1}+e
$$

Tabel 5.

\section{Hasil Pengujian Hipotesis (Uji F)}

\begin{tabular}{|c|c|c|c|c|c|c|}
\hline \multicolumn{7}{|c|}{ ANOVA $A^{b}$} \\
\hline Model & & $\begin{array}{l}\text { Sum of } \\
\text { Squares }\end{array}$ & df & Mean Square & $\mathrm{F}$ & Sig. \\
\hline 1 & Regression & 45,821 & 4 & 11,455 & 8,851 &, $000^{\mathrm{a}}$ \\
\hline & Residual & 187,672 & 145 & 1,294 & & \\
\hline & Total & 233,493 & 149 & & & \\
\hline
\end{tabular}

a. Predictors: (Constant), Penghindaran Risiko, Gratifikasi Personal, Kesadaran Nilai, Integritas

b. Dependent Variable: Sikap pada produk lagu bajakani 
Berdasarkan tabel 5 di atas dapat diketahui bahwa besarnya nilai $\mathrm{F}_{\text {hitung }}$ adalah 8.851 dengan taraf signifikan sebesar 0,000 dan dapat diketahui bahwa pada kolom sig/significance mempunyai angka signifikansi di bawah 0,05 . Oleh karena itu secara simultan variabel Kesadaran Nilai $\left(\mathrm{X}_{1}\right)$, Integritas $\left(\mathrm{X}_{2}\right)$, Gratifikasi Personal $\left(\mathrm{X}_{3}\right)$ dan Penghindaran Risiko $\left(\mathrm{X}_{4}\right)$ berpengaruh Terhadap Sikap Pada Produk Lagu Bajakan (Z). Berdasarkan hasil pengujian maka dapat disimpulkan bahwa secara simultan kesadaran nilai $\left(X_{1}\right)$, integritas $\left(X_{2}\right)$, gratifikasi personal $\left(\mathrm{X}_{3}\right)$ dan penghindaran risiko $\left(\mathrm{X}_{4}\right)$ dapat meningkatkan sikap pada produk lagu bajakan $(\mathrm{Z})$.

Tabel 6.

\section{Hasil Pengujian Hipotesis (uji t)}

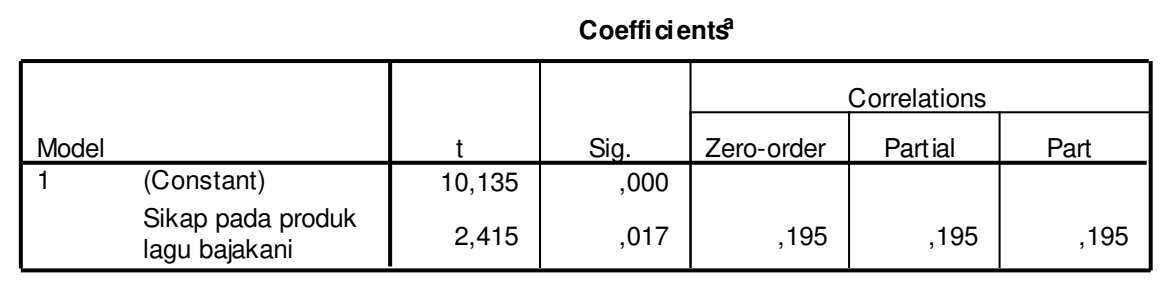

a. Dependent Variable: Niat untuk menggunakan produk

Dari hasil uji t yang tersaji pada Tabel 6 diketahui besarnya nilai koefisien korelasi (r) antara sikap pada produk lagu bajakan dengan niat untuk menggunakan produk lagu bajakan adalah sebesar 0,195 sedangkan besarnya koefisien determinasi yang menunjukkan pengaruh antara sikap pada produk lagu bajakan terhadap niat untuk menggunakan produk lagu bajakan adalah sebesar $(0,195)^{2}=0,0380$ atau 3,80 \%, Nilai $\mathrm{t}$ hitung variabel antara sikap pada produk lagu bajakan adalah 2.415 dengan tingkat signifikansi 0,017 dimana nilainya kurang dari 0,05. Dengan demikian dapat disimpulkan bahwa secara parsial antara sikap pada produk lagu bajakan berpengaruh signifikan terhadap niat untuk menggunakan produk lagu bajakan.

Berdasarkan hasil penelitian dapat diketahui bahwa secara bersama-sama kesadaran nilai, integritas, gratifikasi personal, penghindaran resiko, berpengaruh signifikan terhadap sikap pada produk bajakan. Hasil ini didasarkan pada hasil pengujian regresi linier berganda dengan signifikansi sebesar 0.000 yang berarti secara bersama-sama kesadaran nilai, integritas, gratifikasi personal, penghindaran resiko, berpengaruh terhadap sikap pada produk bajakan. Hal ini berarti bahwa hipotesis $\mathrm{H}_{1}$ terdukung.

Berpengaruh positif dan signifikan dalam penelitian ini mengindikasikan bahwa apabila semakin baik secara bersama-sama kesadaran nilai, integritas, gratifikasi personal, penghindaran resiko maka sikap pada produk bajakan juga akan meningkat. Konsumen yang mempunyai kesadaran nilai tinggi diperkirakan mempunyai sikap terhadap produk bajakan. Hal ini sejalan dengan penelitian terdahulu yang menyatakan bahwa persepsi konsumen yang menganggap produk bajakan mempunyai manfaat fungsional yang sama dengan produk versi asli, dengan harga yang lebih murah (Wang et al., 2005:342).

Konsumen yang mempunyai standar etika yang rendah lebih tidak mempunyai tanggung jawab apabila membeli barang bajakan. Sehingga mereka tidak menganggap bahwa tindakan mereka tidak etis. Jadi, dengan membandingkan dengan konsumen yang mempunyai integritas rendah, maka konsumen yang memiliki integritas tinggi diperkirakan mempunyai sikap negatif terhadap sikap pada produk bajakan (Ang et al., 2001). 
Berdasarkan pengamatan yang dilakukan oleh Bloch et al., (1993), konsumen yang membeli barang bajakan memiliki kepercayaan diri yang rendah, kurang sukses, dan merasa statusnya rendah sehingga kebutuhan untuk memberikan gratifikasi untuk dirinya sendiri pun rendah. Maka, konsumen yang lebih ingin memperoleh gratifikasi personal yang tinggi diperkirakan mempunyai sikap negatif terhadap produk bajakan. Selain itu penelitian ini sejalan dengan penelitian yang dilakukan oleh Ian Phau dan James Ng (2009), hasil dari penelitiannya tersebut adalah bahwa ada pengaruh antara kesadaran nilai, integritas, gratifikasi personal, dan penghindaran risiko terhadap niat untuk menggunakan melalui sikap terhadap produk bajakan.

Hofstede dan Bond, (1984) mengatakan tentang definisi risk aversion yakni sejauh mana seseorang merasa dirinya terancam oleh situasi yang tidak pasti, dan kemudian menciptakan keyakinannya sendiri yang bertujuan untuk mencoba menghindari kondisi ketidakpastian tersebut. Oleh karena pengambilan keputusan konsumen sudah pasti tidak dapat dihindarkan dari adanya faktor risiko, maka konsumen secara otomatis akan menciptakan suatu perilaku tertentu sebagai bentuk pertahanan diri untuk menghindari segala bentuk risiko yang dapat muncul dari keputusannya tersebut. Sementara kepedulian terhadap kesadaran nilai dapat mempengaruhi individu untuk menggunakan produk bajakan, takut terhadap hukuman pidana juga harus dapat mencegah perilaku tersebut (Albers-Miller, 1999). Keuntungan yang didapatkan dalam hal bersikap terhadap musik bajakan mungkin dibatasi oleh rasa takut tertangkap dan dihukum oleh penegak hukum dan akan dijatuhi hukuman. Hal ini dapat dikatakan bahwa hukum hak cipta dan beratnya hukuman menempatkan kontrol perilaku individu atas niat untuk menggunakan produk bajakan. Kemudian disimpulkan dalam Ian Phau dan James Ng (2009) bahwa seseorang yang lebih menghindari risiko lebih cenderung memiliki sikap negatif terhadap produk lagu bajakan.

Berdasarkan hasil penelitian dapat diketahui bahwa sikap pada produk bajakan berpengaruh terhadap niat menggunakan produk. Hasil ini didasarkan pada hasil pengujian regresi linier sederhana dengan signifikansi sebesar 0.017 yang berarti sikap pada produk bajakan berpengaruh signifikan terhadap niat menggunakan produk. Berpengaruh positif dan signifikan dalam penelitian ini mengindikasikan bahwa apabila semakin baik sikap pada produk bajakan maka niat menggunakan produk lagu bajakan akan meningkat.

Niat seseorang untuk menggunakan musik secara ilegal. Seperti yang telah dikemukakan oleh Beck dan Ajzen (1991), bahwa TPB secara akurat mampu memprediksi perilaku tidak jujur seseorang. Sehingga, landasan seseorang untuk menggunakan musik secara ilegal juga dapat diprediksi. Apabila semakin kuat sikap seseorang dalam menggunakan lagu bajakan maka niat akan menggunakan produk music bajakan akan semakin kuat pula.

Pembentukan sikap terjadi akibat pengaruh yang kuat oleh pengalaman pribadi, pengaruh keluarga dan teman, pemasaran langsung, dan media massa. Kemudian disimpulkan dalam Wang dkk. (2009) bahwa semakin positif sikap seseorang terhadap sesuatu, maka makin besar juga niat seseorang dalam

\section{Simpulan}

Berdasarkan analisis dan pembahasan yang telah dilakukan, maka kesimpulan yang dapat diambil adalah bahwa pengaruh secara simultan antara kesadaran nilai, integritas, gratifikasi personal, penghindaran risiko, terhadap sikap pada produk lagu bajakan. Penghindaran risiko memiliki pengaruh yang paling signifikan terhadap sikap pada produk lagu bajakan 
dibandingkan tiga faktor yang lain yang diamati. Lebih lanjut, hasil penelitian menunjukkan bahwa sikap pada produk lagu bajakan berpengaruh terhadap niat menggunakan produk lagu bajakan.

Diharapkan bagi masyarakat untuk mencintai dan menghargai produk asli dari bidang musik yaitu lagu dengan tidak melakukan pembajakan dan mengkonsumsi musik secara legal, selain itu diharapkan bagi konsumen untuk mempertimbangkan dan memastikan risiko sebelum menggunakan lagu bajakan dan akan merugikan industri musik untuk lebih berkembang. Bagi pihak musisi dan pihak-pihak yang terkait dalam usaha mengurangi perilaku mengkonsumsi musik secara ilegal yang semakin meluas di masyarakat, untuk lebih gencar dalam memberikan informasi serta penyuluhan kepada konsumen mengenai dampak negatif dan risiko yang akan dialami oleh baik industri musik Indonesia juga oleh konsumen sendiri. Bagi peneliti selanjutnya disarankan untuk melakukan penelitian di luar variabel bebas yang digunakan dalam penelitian ini mengingat terdapat pengaruh dari variabel lain, ataupun mengkombinasikan variabel sikap pada produk nilai, integritas, gratifikasi personal, penghindaran resiko dengan variabel lain di luar variabel dalam penelitian ini.

\section{Referensi}

Ajzen, I. dan Fishbein, M. 1977. Attitude-Behavior Relations: A Theoretical

Analysis and Review of Empirical Research, Psychology Bulletin, Vol. 84: 888-918.

Albers-Miller, N.D. 1999. Consumer Misbehavior: Why People Buy Illicit Goods. Journal of Consumer Marketing, Vol. 16/3: 273-287

Ang, S.H., Cheng, P.S., Lim, E.A.C., dan Tambyah, S.K. 2001. Spot the Difference: Consumer Responses towards Counterfeits. Journal of Consumer Marketing, Vol. 18/3: 219235

Bao, Y., Zhou, K.Z., dan Su., C. 2003. Face Consciousness and Risk Aversion: Do They Affect Consumer Decision-Making?. Psychology \& Marketing, Vol. 20/8, 2003: 733-755.

Bloch, P.H., Bush, R.F., dan Campbell, L. 1993. Consumer 'accomplices' in Product Counterfeiting: A Demand-side Investigation. Journal of Consumer Marketing. Vol. 10/4: 2736.

Buttle, F. 2004. Customer Relationship Management. Oxford: Elsevier/ButterworthHeinemann.

Chiou, J-S., Huang, C-Y., dan Lee, H-H. 2005. The Antecedents of Music Piracy Attitudes and Intentions. Journal of Business Ethics, Vol. 57: 161-174.

Cordell, V.V., Wongtada, N., dan Kieschnick, Jr., R.L. 1996. Counterfeit Purchase Intentions: Role of Lawfulness Attitudes and Product Traits as Determinants. Journal of Business Research, Vol.35: 41-53. 
Cunningham, L.F., Gerlach, J.H., Harper, M.D., dan Young, C.E. 2004. Perceived Risk and the Consumer Buying Process: Internet Airline Reservations. International Journal of Service Industry Management, Vol. 16/4: 357-372.

Donthu, N. dan Gilliland, D. 1996. The Informecial Shopper. Journal of Advertising Research, Vol. 36: 69-76.

Fraedrich, J.P. dan Ferrell. O.C. 1992. The Impact of Perceived Risk and Moral Philosophy Type on Ethical Decision Making in Organization. Journal of Business Research, Vol. 24: 283-295.

Gupta, P., Gould, S., dan Pola, B. 2004. To pirate or not to Pirate: A Comparative Study of the Ethical Versus Other Influences on the Consumer's Software Acquisition Mode Decision. Journal of Business Ethics, Vol. 55/3: 255-274.

Hofstede, G. dan Bond, M. 1984. The Need for Synergy among Cross-Cultural Studies. Journal of Cross-Cultural Psychology, Vol. 15: 417-433.

Hollinger, R.C., dan Clark, J.P. 1983. Deterrence in the Workplace: Perceived Certainty, Perceived Severity, and Employee Theft. Social Forces, Vol. 62/2: 398-418.

Kotler, Philip, and Kevin Lan Keller. 2012. Marketing Management $14^{\text {th }}$ Edition. Prentice Hall. Upper Saddle River, New Jersey.

Kohlberg, L. 1976. Moral Stages and Moralization: The Cognitive Development Approach in Moral Development and Behaviour Theory. Research and Social Issues, Lickona, T. (ed.) Holt, Rinehart, and Winston: New York: 31-53.

Kwong, K.K., Yau, O.H.M., Lee, J.S.Y., Sin, L.Y.M., dan Tse, A.C.B. 2003. The Effects of Attitudinal and Demographic Factors on Intention to Buy Pirated CDs: The Case of Chinese Consumers. Journal of Business Ethics, Vol. 47: 223-235

Linchestein, Donald R., Richard G. Netemeyer, dan Scot Burten. 1990. Distinguishing coupon proneness from value consciousness: an acquisition-transaction utility theory perspective. Journal of Marketing. Vol. 54/3: 54-67.

Maldonado, C., dan Hume, E.C. 2005. Attitudes toward Counterfeit Products: An Ethical Perspective. Journal of Legal, Ethical, and Regulatory Issues, Vol. 8/2: 105-115.

Malhotra, Naresh K. 2006. Marketing Research An Applied Application $5^{\text {th }}$ edition. Prentice Hall. Upper Saddle River, New Jersey.

Mowen, John C. and Michael Minor. 2001. Perilaku Konsumen Jilid I edisi kelima (terjemahan). PT. Penerbit Erlangga.

Phau, I dan Teah, M., 2009. Devil Wears (Counterfeit) Prada: A Study of Antecedents and Outcomes of Attitudes Toward Counterfeits of Luxuary Brands, Journal of Consumer Marketing, Vol. 26/1: 15-27. 
Sony Kusumasondjaja

Syahrial Ashari
Jurnal Manajemen Bisnis Indonesia

Vol.1, Nomor 2, Feb 2014

Phau, I. dan Ng, J. 2009. Predictors of Usage Intentions of Pirated Software. Journal of Business Ethics, Vol. 94: 23-37.

Schiffman, L. G. dan Kanuk, L. 2013. Consumer Behavior, International edition, New Jersey: Prentice Hall Inc.

Sekaran, U. 2003. Research Methodes for Business: A Skill-Building Approach $4^{\text {th }}$ edition. John Willey \& Son, Inc. United States of America.

Shaari, H. dan Halim, F. 2006. Consumer Purchase or Pirated VCD: Do Non-Price Factors Matter? International Journal of Business and Society, Vol. 7/2: 119-131.

Steenhaut, S. dan Van Kehove, P. 2006. An Empirical Investigation of the Relationships among a Consumer's Personal Values, Ethical Ideology, and Ethical Beliefs. Journal of Business Ethics, Vol. 64/2: 137-155.

Tan, B. 2002. Understanding Consumer Ethical Decision Making with Respect to Purchase of Pirated Software. Journal of Consumer Marketing, Vol. 19/2: 96-111.

Vinson, D. E., Munson, J.M., dan Nakanishi, M. 1977. 'An Investigation of the Rokeach Value Survey for Consumer Research Application', in W. E. Perreault (ed.), Advances in Consumer Research, Vol. 4 (The Association for Consumer Research, Provo, UT): 247-252.

Wang, F., Zhang, H., Zang, H., dan Ouyang, M. 2005. Purchasing Pirated Software: An Initial Examination of Chinese Consumers, Journal of Consumer Marketing, Vol. 22/6: 340351.

Yarrow, K. dan O’Donnell, J. 2009. Gen Buy: How Tweens, Teens, and Twenty-Somethings are Revolutionizing Retail. Jossey-Bass, San Francisco, CA Zeithaml et al 1988

Zeithaml, V.A. 1988. Consumer Perceptions of Price, Quality, and Value: A Means-End Model and Synthesis of Evidence. Journal of Marketing, Vol. 52/3: 2-22. 